\title{
PEMBERHENTIAN KEPALA DAERAH DALAM MASA JABATANNYA
}

\author{
ZAINURI \\ Fakultas Hukum, Universitas Wiraraja Sumenep \\ gprzainuri@yahoo.co.id
}

\begin{abstract}
ABSTRAK
Pemberhentian kepala daerah dapat terjadi 2 (dua) oportunitas. Pertama,'objektif' dalam menyelidiki pelanggaran sumpah/janji jabatan yang dilakukankepala daerah. Atau kedua, 'subjektif' dalam menggunakan kewenangannya yaitumencari celah untuk memberhentikan kepala daerah atas landasan sentimentil.Tujuan penelitian ini untuk mengkaji tentang pemberhentian kepala daerah dalammasa jabatannya dan mengkaji lembaga-lembaga yang berwenang melaksanakanmekanisme pemberhentian kepala daerah dan juga permasalahan dalampemberhentian kepala daerah termasuk mengkaji Putusan terkait prosespemberhentian kepala daerah. alasan pemberhentian kepala daerahdiatur dalam Pasal 78 ayat (1) dan ayat (2) UU No. 23 Tahun 2014 tentangPemerintahan Daerah (UUPD), alasan pemberhentian itu belum ada batasan dantolok ukur, ada beberapa masalah yang muncul dalam mekanismepemberhentian kepala daerah yaitu kepala daerah dipilih secara langsung namunpemberhentiannya secara tidak langsung (perwakilan) melalui DPRD sehinggatidak sejalan dengan demokrasi, kemudian otonomi daerah tidak dilaksanakandengan leluasa sebab masih ada peran pemerintah pusat dan juga belum adanyalembaga yudikatif di daerah yang khusus untuk pemberhentian kepala daerah.
\end{abstract}

Kata Kunci : Pemberhentian Kepala Daerah dalam Masa Jabatnannya.

\section{A. PENDAHULUAN}

Landasan fundamental adanya otonomi daerah menjadi dasar bahwa hak-hak yang dimiliki oleh Dewan Perwakilan Rakyat (DPR) turut pula dimiliki olehDewan Perwakilan Rakyat Daerah (DPRD). Hanya saja konteks kerjasama DPRdengan Presiden, pada demokrasi tingkat lokal representatif masyarakat yaitu 2DPRD memiliki hubungan dengan kepala daerah sebagai penyelenggara pemerintahan daerah.

Selain mengonstruksi demokrasi di atas suatu landasan yang kuat, perlujuga menjamin permanensinya. Kebijakan yang sejati bukanlah kebijakan yangmenjamin jumlah demokrasi yang sebesar mungkin, tetapi kebijakan yangmenjamin keberlangsungannya yang selama mungkin.

Saat ini proses demokrasi di Indonesia telah memasuki tahapperkembangan yang sangat penting. Perkembangan itu ditandai dengan berbagaiperubahan dalam sistem dan struktur kekuasaan Negara. Kewenangan pemerintahan yang tadinya sangat terpusat di Jakarta kini semakin terdistribusi kepemerintahan di daerah-daerah melalui proses desentralisasi.

Kaitan pokok antara pembaruan hukum dengan demokratisasi adalahpemahaman bahwa pembaruan hukum merupakan bagian dari prosesinstitusionalisasi nilai-nilai dan perilaku demokratis. Dalam hal ini pembaruanhukum harus dilakukan untuk 
melembagakan prosedur demokratis sebagai polapengaturan, pengambilan keputusan, dan penyelesaian konflik di tengahmasyarakat.

Dari segi ketatanegaraan, masalah pemerintahan daerah adalah merupakansalah satu aspek struktural dari suatu negara, dan perihal pemerintah/pemerintah daerah itu sendiri, serta hubungannya dengan pemerintah pusatnya tergantungkepada bentuk dan susunan negaranya.

Mekanisme pemberhentian kepala daerah, perlu diketahui pihak-pihakyang memiliki wewenang untuk memberhentikan kepala daerah. Kewenanganterkait pemberhentian kepala daerah secara struktural masih melibatkanpemerintah pusat, karena proses panjang pemberhentian kepala daerah ituberujung pada surat keputusan Presiden atau Menteri Dalam Negeri. Kewenanganitu sebagai wujud dari demokrasi prosedural bukan demokrasi langsung.

Perlu diingat bahwa frasa pelanggaran etika dan peraturan perundang-undangan merupakan satu kesatuan dan bersifat kumulatif, sedangkan MahkamahAgung hanya membuktikan pelanggaran perundangundangannya saja tanpamengutarakan alasanalasan terkait pelanggaran etika yang dilakukan oleh Dr.(HC) Kena Ukur Karo Jambi Surbakti selaku Bupati Karo. Meskipun putusanMahkamah Agung tidak ultra petita karena berdasarkan pada permohonan DPRD,namun perlu dilihat alasan-alasan kepala daerah diberhentikan haruslah dimohonkan dan diputuskan atas dasar undang-undang.

Faktanya, pemberhentian kepala daerah yang masih memiliki campurtangan pusat dalam hal ini bermuara pada keputusan Presiden pada hakikatnyatidak mencerminkan wujud otonomi daerah dan juga tidak senada dengandemokrasi. Politisnya proses pemberhentian kepala daerah dalam masa jabatannyaperlu diberikan suatu langkah yang solutif agar pemerintahan daerah dapat berjalan dengan baik. Selain itu belum adanya tolok ukur pelanggaran etika,sumpah/janji kepala daerah menjadi problematika yang krusial karena tidakadanya batasan sebagaimana pelanggaran peraturan perundang-undangan.

Hugo Grotius menyatakan bahwa setiap orang mempunyai kecendrunganhidup bersama. Tidak hanya itu, karena memiliki rasio, manusia itu juga inginhidup secara damai. Begitulah, Grotius menjadikan sosiabilitas manusia sebagailandasan ontologi dan fondasi segala hukum. Maka, hukum sangat dibutuhkanagar tiap orang kembali pada kodratnya sebagai 'manusia sosial' yang berbudi.

Hukum, dengan demikian, merupakan 'pengawal' dalam sosiabilitiasmanusia untuk menjamin agar prinsip-prinsip 'individu sosial' yang berbudi itutetap tegak. Prinsipprinsip dimaksud adalah: (1) Milik orang lain harus dihormati.(2) Kesetiaan pada janji. Kontrak harus dihormati (pacta sunt servanda) (3) Harusada ganti rugi untuk tiap kerugian 
yang diderita (4) Harus ada hukuman untuksetiap pelanggaran.

Konstitusi sebagai aturan tertinggi dalam tatanan hukum positif diIndonesia telah mengatur mengenai otonomi daerah sebagaimana yang termaktubdalam Pasal 18 UUD NRI Tahun 1945 memuat bahwa "Pembagian daerahIndonesia atas daerah besar dan kecil dengan bentuk susunan pemerintahannyaditetapkan dengan undangundang, dengan memandang dan mengingat dasar permusyawaratan dalam sistem pemerintah negara dan hak-hak asal usul dalamdaerah-daerah yang bersifat istimewa".

Pasal 18 ayat (4) UUD NRI Tahun 1945 menentukan bahwa "Gubernur,Bupati dan Walikota masing-masing sebagai kepala pemerintah daerah provinsi,kabupaten dan kota dipilih secara demokratis". Pemaknaan arti kata demokratisdalam ketentuan tersebut dengan memilih mekanisme pemilihan secara langungsebagaimana diatur dalam UndangUndang Nomor 32 Tahun 2004 tentangPemerintahan Daerah. Pasal 24 ayat (5) menentukan bahwa kepala daerah danwakil kepala daerah dipilih dalam satu pasangan secara langsung oleh rakyat didaerah yang bersangkutan.

Implikasi otonomi daerah, memberikan adanya hubungan antara kepaladaerah dan DPRD. Selain konstitusi, peraturan organik terhadap otonomi daerah,telah diatur lebih lanjut dalam Undang-Undang Nomor 23 Tahun 2014 tentangPemerintahan Daerah. Dalam undang-undang itu, turut mengatur mengenaipemberhentian kepala daerah yang didasarkan atas penggunaan fungsi dan hakDPRD.

Otonomi haruslah menjadi salah satu sendi susunan pemerintahan yangdemokratis. Artinya, di negara demokrasi dituntut adanya pemerintahan daerahyang memperoleh hak otonomi. Adanya pemerintah daerah yang demikian jugamenyempurnakan suatu ciri negara demokrasi, yakni kebebasan. Tocquevilleseperti dikutip oleh Rienow mengatakan suatu pemerintahan merdeka tanpasemangat membangun institusi pemerintahan tingkat daerah sama artinya dengan tidak mempunyai semangat kedaulatan rakyat, karena di sana tidak ada semangatkebebasan.

Kesimpulan ini muncul karena salah satu karakter demokrasi adalahadanya kebebasan. Rienow sendiri mengatakan ada dua alasan pokok darikebijaksanaan membentuk pemerintahan di tingkat daerah. Pertama, membangunkekuasaan agar rakyat memutuskan sendiri berbagai kepentingan yang berkaitanlangsung dengan mereka. Kedua, memberikan kesempatan kepada masing-masing komunitas yang mempunyai tuntutan yang berbeda untuk membuat aturanaturandan programnya sendiri.

\section{B. PEMBAHASAN}

Menurut Hans Kelsen, bahwa: "yang disebut otonomi daerah adalah suatuperpaduan langsung dari ide-ide desentralisasi dengan ide-ide demokrasi. 
Organ-organ pembuat norma-norma daerah dipilih oleh para subyek dari norma-normaini"

Seberapa besar kewenangan otonomi daerah menuju kemandirian daerahdi dalam Negara Kesatuan, sangat bergantung pada sistem dan kehendak politikpemerintah pusat untuk memberikan kemandirian pemerintah daerah. Hanya saja,betapapun kemandirian itu diberikan, tidak dapat diartikan pemerintah daerahmelaksanakannya secara absolut saat melaksanakan hak dan fungsi otonominyamenurut kehendaknya sendiri. Pemerintah daerah harus tetap memerhatikan keberadaan pemerintah pusat dan kepentingan daerah lain sebagai keseluruhandalam ikatan Negara kesatuan.

Prinsip pembagian kekuasaan atau kewenangan pada negara kesatuanadalah: Pertama, kekuasaan atau kewenangan pada dasarnya milik pemerintahpusat, daerah diberi hak dan kewajiban mengelola dan menyelenggarakan sebagian kewenangan pemerintahan yang dilimpahkan atau diserahkan. Jadi,terjadi proses penyerahan atau pelimpahan kewenangan. Kedua, pemerintah pusatdan pemerintah daerah tetap memiliki garis komando dan hubungan hierarkis.Pemerintah sebagai subordinasi pemerintah pusat, namun hubungan yangdilakukan tidak untuk mengintervensi dan mendikte pemerintah daerah dalamberbagai hal. Ketiga, kewenangan atau kekuasaan yang dialihkan atau diserahkankepada daerah dalam kondisi tertentu, di mana daerah tidak mampu menjalankandengan baik, maka kewenangan yang dilimpahkan dan diserahkan tersebut dapatditarik kembali ke pemerintah pusat sebagai pemilik kekuasaan atau kewenangantersebut.

Konsep pemisahan kekuasaan juga dikemukakan oleh Montesquieu dalambukunya 'L'Espirit des Lois". Montesquieu membagi kekuasaan negara dalamtiga cabang, yaitu: (i) legislatif sebagai pembuat undang-undang;

kekuasaaneksekutif yang melaksanakan; dan (iii) kekuasaan untuk menghakimi atauyudikatif. Dari klasifikasi Montesquieu inilah dikenal pembagian kekuasaannegara modern dalam tiga fungsi, yaitu legislatif (the legislative function), eksekutif (the executive or administrative function), dan yudisial (the judicialfunction).

Wewenang adalah pengertian yang berasal dari hukum organisasipemerintahan, yang dapat dijelaskan sebagai keseluruhan aturan-aturan yangberkenaan dengan perolehan dan penggunaan wewenangwewenang pemerintahanoleh subyek hukum publik di dalam hubungan hukum publik.

Cabang kekuasaan legislatif adalah cabang kekuasaan yang pertamatamamencerminkan kedaulatan rakyat. Kegiatan bernegara, pertama-tama adalah untukmengatur kehidupan bersama. Oleh sebab itu, kewenangan untuk menetapkanperaturan itu pertama-tama harus diberikan kepada lembaga perwakilan rakyatatau parlemen atau lembaga legislatif. 
Otonomi luas dimaksudkan bahwa kepala daerah diberikan tugas,wewenang hak, dan kewajiban untuk menangani urusan pemerintahan yang tidakditangani oleh pemerintah pusat sehingga isi otonomi yang dimiliki oleh suatudaerah memiliki banyak ragam dan jensinya. Di samping itu, daerah diberikankeleluasaan untuk menangani urusan pemerintahan yang diserahkan itu dalamrangka mewujudkan tujuan dibentuknya suatu daerah dan tujuan pemberianotonomi itu sendiri terutama dalam memberikan pelayanan kepada masyarakatsesuai dengan potensi dan karakteristik masing-masing daerah.

Prinsip otonomi nyata adalah suatu tugas, wewenang, dan kewajiban untukmenangani urusan pemerintahan yang senyatanya telah ada dan berpotensi untuktumbuh dan berkembang sesuai dengan potensi dan karakteristik daerah masing-masing. Dengan demikian, isi dan jenis otonomi daerah bagi setiap daerah tidak selalu sama dengan daerah lainnya. Sementara itu, otonomi yangbertanggungjawab adalah otonomi yang dalam penyelenggaraannya harus benar-benar sejalan dengan tujuan pemberian otonomi yang pada dasarnya untukmemberdayakan daerah termasuk meningkatkan kesejahteraan rakyat.

Betapapun luasnya otonomi yang dimiliki oleh suatu daerah,pelaksanaannya harus tetap dalam kerangka Negara Kesatuan Republik Indonesia.Di samping itu, penyelenggaraan otonomi harus menjamin adanya hubungan yangserasi antara masyarakat, pemerintah daerah, dan DPRD. Kinerja penyelenggaraanotonomi daerah, yaitu Pemerintah Daerah dan DPRD, harus selalu berorientasipada peningkatan kesejahteraan dan pelayanan kepada masyarakat dengan selalumemerhatikan kepentingan dan aspirasi masyarakat luas.

Berbagai isu negatif yang berkembang dalam masyarakat tentangpelaksanaan otonomi daerah yang dikaitkan dengan pemicu terjadinya disintegrasibangsa, sungguh memprihatinkan di tengah harapan rakyat agar memperolehpenghidupan yang lebih baik. Fenomena ini, dapat membangun “image negatif"dengan menggunakan pelbagai cara, padahal otoda merupakan konkretisasi dariasas desentralisasi yang memberikan kewenangan lebih besar kepada pemerintahdaerah/kota untuk menyelenggarakan pemerintahan dan pembangunannya sendiri,tetapi tetap dalam keutuhan NKRI.

Idealnya hubungan kemitraan yang seimbang, pemerintah daerah danDPRD menciptakan berbagai instrumen yang dilandaskan tanggung jawabbersama baik dalam formulasi, implementasi maupun evaluasinya, sehinggaterjadi penyimpangan bukanlah kepala eksekutifnya yang diturunkan dari jabatankepala daerah, akan tetapi bersama-sama memperbaikinya melalui mekanismeyang ada.

Negara Kesatuan Republik Indonesia dibagi atas Republik Indonesiadibagi atas 
daerah-daerah propinsi dan daerah propinsi itu dibagi atas kabupatendan kota, yang tiap-tiap propinsi, kabupaten, dan kota itu mempunyaipemerintahan daerah mengatur dan mengurus sendiri urusan pemerintahanmenurut asas otonomi dan tugas pembantuan sebagaimana tercantum dalam Pasal18 ayat (1) dan ayat (2) Undang-Undang Dasar Negara Republik Indonesia Tahun1945. Indonesia saat ini sedang mengalami transformasi kekuasaan seperti yangtelah diteliti oleh Institute of Development Studies, University of Sussex di Inggris.Sejak runtuhnya Orde Baru, gelombang reformasi telah mengubah format politikdan sistem pemerintahan di tanah air.

Jean Bodin mengutarakan bahwa hukum (ius) adalah baik dan adil tanpaperintah. Sedangkan perundang-undangan (leges) dihasilkan dari penerapan kedaulatan orang yang memerintah. Implisit ia membedakan hukum sebagaiperundang-undangan, dengan hukum yang bersumber dari moral dan keadilan.Dalam teorinya tentang legis actio (realisasi hukum), menurut Bodin realisasihukum bisa terjadi di dalam maupun di luar pengadilan.

Law as a tool of social engineeringdapat pula diartikan sebagai saranayang ditujukan untuk mengubah perilaku warga masyarakat, sesuai dengantujuan-tujuan yang telah ditetapkan sebelumnya.Salah satu masalah yang dihadapidi dalam bidang ini adalah apabila terjadi apa yang dinamakan oleh GunnarMyrdal sebagaisoft developmentyaitu dimana hukum-hukum tertentu yangdibentuk dan diterapkan ternyata tidak efektif.

Pemberhentian kepala daerah melalui 2 (dua) prosedur realisasi hukumsekaligus yaitu di dalam dan di luar pengadilan. Fungsi dan hak DPRD sebagaiwujud realisasi hukum di luar pengadilan, kewenangan DPRD memiliki implikasiterhadap pemberhentian kepala daerah untuk menegakkan nilai moral dankeadilan untuk kepentingan masyarakat Indonesia umumnya dan untukmasyarakat di daerah khususnya. Setelah itu, ada mekanisme melalui pengadilanyaitu di Mahkamah Agung, DPRD mengajukan permohonan kepada Mahkamah Agung atas dugaan pelanggaran sumpah/janji jabatan kepala daerah.

Kekuasaan negara dibataskan sedemikian rupa hingga bukan saja segalakekuasaan dari penguasa berdasarkan undang-undang, tetapi juga bahwa kekuasaan dari alat-alat pemerintah ini bersumber pada dan berakar dalamhukum.

Pijakan hukum fundamental selain mengenai otonomi daerah yang terkaitdengan pemberhentian kepala daerah dalam masa jabatannya diatur dalambeberapa atuan dalam hukum positif di Indonesia. Pertama, UndangUndangNomor 2 Tahun 2018 tentang Perubahan Kedua Atas Undang-Undang Nomor 17Tahun 2014 tentang Majelis Permusyawaratan Rakyat, Dewan Perwakilan Rakyat,Dewan Perwakilan Daerah, dan Dewan Perwakilan Rakyat Daerah. Kedua,Undang-Undang Nomor 23 Tahun 2014 tentang Pemerintahan Daerah. 
Ketiga,Peraturan Pemerintah Republik padamekanisme-mekanisme berikutnya Indonesia Nomor 12 Tahun 2018 (melalui lembaga yang berwenang) tentangPedoman Penyusunan Tata Tertib danberimplikasi terhadap pemberhentian Dewan Perwakilan Rakyat Daerah kepala daerah.

Provinsi,Kabupaten, Dan Kota.

Pasal 78 ayat (2) UUPD memuat bahwa:

Alasan-alasan pemberhentian kepala Selanjutnya ditegaskan bahwaKepala daerah daerah pada masing-masing negaraberbeda- dan/atau wakil kepala daerah berhenti karena beda. Selain itu, perdebatan mengenai penafsiran alasan pemberhentiankepala daerahjuga mewarnai proses pemberhentian kepala daerahatau menjadiwacana eksplorasi pengembangan teori dari sisi akademis. Menurut JimlyAssiddiqie, mengenai mekanisme pemberhentian kepala daerah di negara-negarayang mengadopsi ketentuan ini juga berbeda-beda. Namun secara umum,mekanisme pemberhentian kepala daerah pasti melalui sebuah proses peradilantata negara, yang melibatkan lembaga yudikatif, baik lembaga itu adalah Mahkamah Agung (supreme court) atau Mahkamah Konstitusi (constitutionalcourt).

Alasan-alasan pemberhentian kepala daerah dalam masa jabatannyabermula dari adanya pelanggaran terhadap tugas, wewenang, kewajiban,melakukan perbuatan yang dilarang maupun pelanggaran lainnya yang diaturdalam undang-undang yang secara umum terkait dengan pelanggaran sumpah/janji jabatan kepala daerah maka DPRD dapat memberdayakan fungsi pengawasan (controlling) dengan menjalankan hak interpelasi, hak angket, danhak menyatakan pendapatnya terhadap kepala daerah hingga berlanjut

“diberhentikan"sebagaimana dimaksud pada ayat (1) huruf c karena:

a. berakhir masa jabatannya;

b. tidak dapat melaksanakan tugas secara berkelanjutan atau berhalangantetap secara berturut-turut selama 6 (enam) bulan;

c. dinyatakan melanggar sumpah/janji jabatan kepala daerah;

d. tidak melaksanakan kewajiban kepala daerah sebagaimana dimaksuddalam Pasal 67 huruf b;

e. melanggar larangan bagi kepala daerah sebagaimana dimaksud dalamPasal 76 ayat (1), kecuali huruf c, huruf $i$, dan huruf $j$;

f. melakukan perbuatan tercela;

g. diberi tugas dalam jabatan tertentu oleh Presiden yang dilarang untuk dirangkap oleh ketentuan peraturan perundangundangan;

h. menggunakan dokumen dan/atau keterangan palsu sebagai persyaratanpada saat pencalonan kepala daerah berdasarkan pembuktian darilembaga yang berwenang menerbitkan dokumen; dan/atau

i. mendapatkan sanksi pemberhentian. 


\section{PENUTUP}

Alasan-alasan pemberhentian kepala daerah dalam masa jabatannyabermula dari adanya fungsi pengawasan (controlling) denganmenjalankan hak interpelasi, hak angket, dan hak menyatakanpendapatnya DPRD terhadap dugaan pelanggaran yang dilakukan olehkepala daerah. Diatur dalam Pasal 78 ayat (1) dan ayat (2) UUPD, alasanpemberhentian itu belum ada batasan dan tolok ukur maupun aturan yanglebih rinci terhadap pelanggaran-pelanggaran yang dapat dijadikan alasanpemberhentian kepala daerah. Penerapan pemberhentian kepala daerah dalam Putusan MahkamahAgung Nomor: 01/P/KHS/2014 terdapat beberapa kejanggalan. Pertama,mengenai permasalahan mengutus Sekretaris Daerah dalam Rapat DPRDKabupaten Karo, itu diperbolehkan secara yuridis sebagaimana yangdiatur dalam Pasal 72 ayat (1) dan (2) PP Tatib DPRD. Kedua,berubahnya frasa dalam Pasal 29 ayat (2) huruf d UU No. 32 Tahun 2004menjadi Pasal 78 ayat (2) huruf c UU No. 23 Tahun 2014 karena tidaklagi mengatur mengenai pelanggaran sumpah/janji yang dilakukan olehkepala daerah bersama-sama dengan wakil kepala daerah. Ketiga, alasan-alasan dalam putusan Mahkamah Agung tersebut secara universalmenyatakan pelanggaran terhadap peraturan perundang-undangan sajasedangkan dasar permohonan DPRD dalam bentuk kumulatif yaituadanya pelanggaran etika dan peraturan perundangundangan dan tidaksatupun ada alasan mengenai pelanggaran etika. Keempat, keterangansaksi Eka Jaya Sitepu dan Saksi Raja Edward Sebayang yang tidakdipertimbangkan, Kemudian UUPD 32/2004 juga belum secara tegasmengatur sanksi kepala daerah yang terlibat dalam yayasan.

\section{DAFTAR PUSTAKA}

Abdul Aziz Hakim. 2018. Impeachment Kepala Daerah. Yogyakarta: PustakaPelajar.

Achmad Ali. 2015. Menguak Tabir Hukum. Jakarta: Prenadamedia Group.

Aristoteles. 2017. Politik. Yogyakarta: NarasiPustaka Promethea.

Bernard L. Tanya., dkk. 2013. Teori Hukum: Strategi Tertib Manusia LintasRuang dan Generasi. Yogyakarta: Genta Publishing.

Eka N.A.M. Sihombing. 2018. Pembentukan Peraturan Daerah Partisipatif.Malang: Inteligensia Media.

Hendra Karianga. 2017. Carut-Marut Pengelolaan Keuangan Daerah di EraOtonomi Daerah Perspektif Hukum dan Politik. Depok: Kencana.

Jimly Asshiddiqie. 2010. Perkembangan \& Konsolidasi Lembaga Negara PascaReformasi. Jakarta: Sinar Grafika.

M. Solly Lubis. 2014. Ilmu Negara Edisi Revisi. Bandung: CV. Mandar Maju.

Marwan Mas. 2018. Hukum Konstitusi dan Kelembagaan Negara. Depok:Rajawali Pers. 
Moh. Mahfud MD. 2009. Politik Hukum di Indonesia. Jakarta: PT Raja Grafindo Persada.

Peter Mahmud Marzuki. 2014. Penelitian Hukum. Jakarta: Prenada Media Group.

Undang-Undang Dasar Negara Republik Indonesia Tahun 1945.

Undang-Undang Nomor 9 Tahun 2015 tentang Perubahan Kedua UndangUndangNomor 23 Tahun 2014 tentang Pemerintahan Daerah.
Undang-Undang Nomor 2 Tahun 2018 tentang Perubahan Kedua Atas Undang-Undang Nomor 17 Tahun 2014 Tentang Majelis Permusyawaratan Rakyat,Dewan Perwakilan Rakyat, Dewan Perwakilan Daerah, Dan DewanPerwakilan Rakyat Daerah.

Peraturan Pemerintah Republik Indonesia Nomor 12 Tahun 2018 TentangPedoman Penyusunan Tata Tertib Dewan Perwakilan Rakyat DaerahProvinsi, Kabupaten, Dan Kota 